\title{
Climatic and ecological drivers of euphausiid community structure vary spatially in the Barents Sea: relationships from a long time series (1952-2009)
}

\section{Emma L. Orlova ${ }^{1+}$, Andrey V. Dolgov ${ }^{1 *}$, Paul E. Renaud ${ }^{2,3}$, Michael Greenacre $^{2,4}$, Claudia Halsband ${ }^{2}$ and Victor A. Ivshin ${ }^{1,5}$}

' Laboratory of Trophology, Polar Research Institute of Marine Fisheries and Oceanography, Murmansk, Russia

${ }^{2}$ Akvaplan-niva, Fram Centre for Climate and Environment, Tromsø, Norway

${ }^{3}$ Department of Arctic Biology, University Centre in Svalbard, Longyearbyen, Norway

${ }^{4}$ Barcelona Graduate School of Economics, Universitat Pompeu Fabra, Barcelona, Spain

${ }^{5}$ Laboratory of Fisheries Oceanography, Polar Research Institute of Marine Fisheries and Oceanography, Murmansk, Russia

\section{Edited by:}

Paul F. J. Wassmann, University of

Tromsø - Norway's Arctic University, Norway

\section{Reviewed by:}

Jan Marcin Weslawski, Institute of

Oceanology Polish Academy of

Sciences, Poland

Rolf Gradinger, University of Alaska

Fairbanks, USA

\section{*Correspondence:}

Andrey V. Dolgov, Laboratory of Trophology, Polar Research Institute of Marine Fisheries and

Oceanography, Knipovich-St., 6,

Murmansk 183038, Russia

e-mail:dolgov@pinro.ru

${ }^{\dagger}$ Deceased.
Euphausiids play an important role in transferring energy from ephemeral primary producers to fish, seabirds, and marine mammals in the Barents Sea ecosystem. Climatic impacts have been suggested to occur at all levels of the Barents Sea food-web, but adequate exploration of these phenomena on ecologically relevant spatial scales has not been integrated sufficiently. We used a time-series of euphausiid abundance data spanning 58 years, one of the longest biological time-series in the Arctic, to explore qualitative and quantitative relationships among climate, euphausiids, and their predators, and how these parameters vary spatially in the Barents Sea. We detected four main hydrographic regions, each with distinct patterns of interannual variability in euphausiid abundance and community structure. Assemblages varied primarily in the relative abundance of Thysanoessa inermis vs. T. raschii, or T. inermis vs. T. longicaudata, and Meganyctiphanes norvegica. Climate proxies and the abundance of capelin or cod explained $30-60 \%$ of the variability in euphausiid abundance in each region. Climate also influenced patterns of variability in euphausiid community structure, but correlations were generally weaker. Advection of boreal euphausiid taxa from the Norwegian Sea is clearly more prominent in warmer years than in colder years, and interacts with seasonal fish migrations to help explain spatial differences in primary drivers of euphausiid community structure. Non-linear effects of predators were common, and must be considered more carefully if a mechanistic understanding of the ecosystem is to be achieved. Quantitative relationships among euphausiid abundance, climate proxies, and predator stock-sizes derived from these time series are valuable for ecological models being used to predict impacts of climate change on the Barents Sea ecosystem, and how the system should be managed.

\section{Keywords: Arctic, capelin, cod, krill, pelagic food web}

\section{INTRODUCTION}

Euphausiids in many high latitude ecosystems are important food for fish, seabirds, and mammals (Nilssen et al., 1995; Mehlum, 2001; Lindstrøm et al., 2013). In the Barents Sea, these lipid-rich zooplankton may represent up to $60 \%$ of the diet of capelin when centers of abundance of the two taxa overlap (e.g., Dalpadado and Mowbray, 2013). The share of lipid-rich food in capelin diets can determine their overwintering success and reproductive output during the next year (Orlova et al., 2010a,b). In addition, early year-classes of cod (Gadus morhua) and haddock (Melanogrammus aegelfinus) may feed heavily upon euphausiids in some regions of the Barents Sea (Ponomarenko, 1973; Ponomarenko and Yaragina, 2003; Dalpadado et al., 2009; Renaud et al., 2012), as will adult cod and haddock (Kovtsova et al., 1989; Drobysheva, 1994; Orlova et al., 2001). Due to these trophic relationships, euphausiid biomass and abundance have been the subject of monitoring efforts in the Barents Sea for almost six decades.

The Polar Research Institute of Marine Fisheries and Oceanography (PINRO, Murmansk, Russia) has conducted annual plankton surveys in most regions of the Barents Sea since 1952. Some of the most relevant findings from these studies include the coupling of population cycles of euphausiids with decadal climatic oscillations, links between capelin and euphausiid biomass, and the share of euphausiids in capelin (Mallotus villosus) and cod diets (Drobysheva, 1994; Orlova et al., 2001, 2010a, 2013; Dalpadado et al., 2003). The entire data series, however, has not been investigated in detail in a single study, and identification of responses to long-term trends in climate requires such long data series. Climatic shifts are implicated 
in impacting the distribution, development and composition of euphausiid communities (Gómez-Gutiérrez et al., 1995; Brinton and Townsend, 2003; Dorman et al., 2011), as well as predatory fish and seabird populations (Abraham and Sydeman, 2004; Sydeman et al., 2006; Coyle et al., 2011), in other areas of the world's oceans. Since climatic warming is already being felt in the Barents region, understanding and quantifying long-term trends in euphausiid response to warming and different predator stocks is important to build both conceptual and mathematical models of the future Barents Sea food web.

The Barents Sea ecosystem has been described as being structured by top-down processes (Dalpadado and Skjoldal, 1996), bottom-up processes (Drinkwater, 2006), or "wasp-waist" regulation, i.e., controlled by planktivorous fish populations (Yaragina and Dolgov, 2009). Different conclusions, however, may be a consequence of the particular species receiving the most focus or the time period studied. Climate oscillations have been implicated in determining the alternating top-down and bottom-up structuring of the Bering Sea pelagic food web (Hunt et al., 2002), and a similar mechanism may operate in the Barents Sea. Recently, a 40y time series was used to suggest that the krill-planktivorous fish relationship alternated between top-down and bottom-up structuring in the Barents Sea (Johannesen et al., 2012). The recent warming, however, appears to overwhelm typical climate oscillation patterns (e.g., Eriksen and Dalpadado, 2011; Dalpadado et al., 2012; Johannesen et al., 2012; Orlova et al., 2013), indicating the need for longer time series and more complex modeling techniques.

There are four main species of euphausiids in the Barents Sea. Thysanoessa raschii is a neritic resident and reproduces in the colder waters of the Barents Sea (Drobysheva, 1994). T. inermis is the most abundant species in the Barents Sea, consisting both of locally reproducing populations and populations advected into the region from the Norwegian Sea (Drobysheva, 1982). These two species have historically made up the majority of the euphausiid community in the Barents Sea (e.g., Drobysheva, 1994). T. longicaudata and Meganyctiphanes norvegica are boreal species that spawn in the Norwegian Sea and arrive in the Barents Sea via warm ocean currents (e.g., Drobysheva, 1994; Zhukova et al., 2009). Only within the last 10 years have these two species been common inhabitants in this region (Dalpadado and Skjoldal, 1996; Buchholz et al., 2010). T. inermis and T. raschii reproduce in the southern Barents Sea (e.g., Zelikman, 1958, 1964), and T. raschii has recently been observed to spawn in Spitsbergen/Svalbard fjords (Buchholz et al., 2012). All four species complete their life cycles in 2-4 years, and all undergo dramatic seasonal vertical migrations where nearly the entire populations spend the winter months in near-bottom waters (e.g., Mauchline, 1980). Whereas there are some similarities in biology and overlap in distribution, the different species have distinct affinities for specific water masses, advective processes determine their population cycles differently, and they vary (in time and space) in terms of their contribution to fish diets. These traits indicate the importance of conducting studies that consider how species compositions vary among regions. This is an approach that has been little used in the Barents Sea region (but see Orlova et al., 2013), where primary questions until now have centered on euphausiid biomass in general, and on interannual variability in prey resources for cod and capelin (e.g., Eriksen and Dalpadado, 2011). Only through this regional approach, however, can mechanisms responsible for determining community structure be identified, and environmental and biological drivers of these processes be explored.

In order to identify environmental and ecological impacts of euphausiids in the pelagic ecosystem, and ultimately their support of commercial fishes, seabirds, and mammal stocks, we analyzed a unique long-term data series within a multi-species and spatially-defined framework. Specifically, we asked: (1) how has euphausiid community structure varied over the duration of the time series within different hydrographically-defined regions in the Barents Sea? (2) what are the qualitative and quantitative effects of different climate indicators and fish stock sizes on populations of overwintering euphausiids? and (3) how can this new understanding be used to predict pelagic ecosystem structure and function in response to expected changes in oceanographic and biological drivers?

\section{METHODS \\ THE EUPHAUSIID DATA SERIES}

The Barents Sea is a relatively shallow-water sea, most of the area being less than 300-400 m. Between 1952 and 2009, data on the distribution, abundance, and species composition of euphausiids in the Barents Sea (Table S1, Figure 1) were collected annually during autumn-winter (October-March). This represents one of the most extensive biological time-series available in the Arctic in time and area covered, and data on species composition and abundance have been published for some of the years (Drobysheva, 1982, 1994; Orlova et al., 2001; Zhukova et al., 2009). The winter period was chosen because: (1) most planktonic species have reduced diurnal vertical migration and occur in a more limited range of depths than during the spring and summer, and (2) this season follows the period when fishes feed intensively on euphausiid stocks. Consequently, the estimates of euphausiid distribution and abundance in this season are consistent, reflect the state of euphausiids stock at the end of feeding season, and are useful for forecasting euphausiid stock size and food-resource state for commercial fish in the next year.

To collect euphausiids, a net (diameter $50 \mathrm{~cm}, 0.2 \mathrm{~m}^{2}$ opening area, $564 \mu \mathrm{m}$ mesh size) was attached to the headline of a bottom trawl. Euphausiids were sampled at 6-10 $\mathrm{m}$ above the bottom (the upper edge of the vertical opening of the bottom trawl). Individuals with body length $>6-7 \mathrm{~mm}$ were in the catches. Euphausiids from most samples were identified to the species level and abundances were expressed as number of individuals per $1000 \mathrm{~m}^{3}$. The season and the sampling net were chosen in the 1950s after some experiments with timing of sampling and net shape and orientation (Orlova et al., 2008). This approach has been the standard at PINRO for estimation of euphausiid stock in the Barents Sea since the 1960s (Drobysheva, 1994), greatly enhancing data comparability. Community structure for a given year is represented by catches of the overwintering community during the winter months following the main growing season (i.e., euphausiid data for 1970 are from samples collected October 1970-March 1971). This allows matching of climatic conditions 


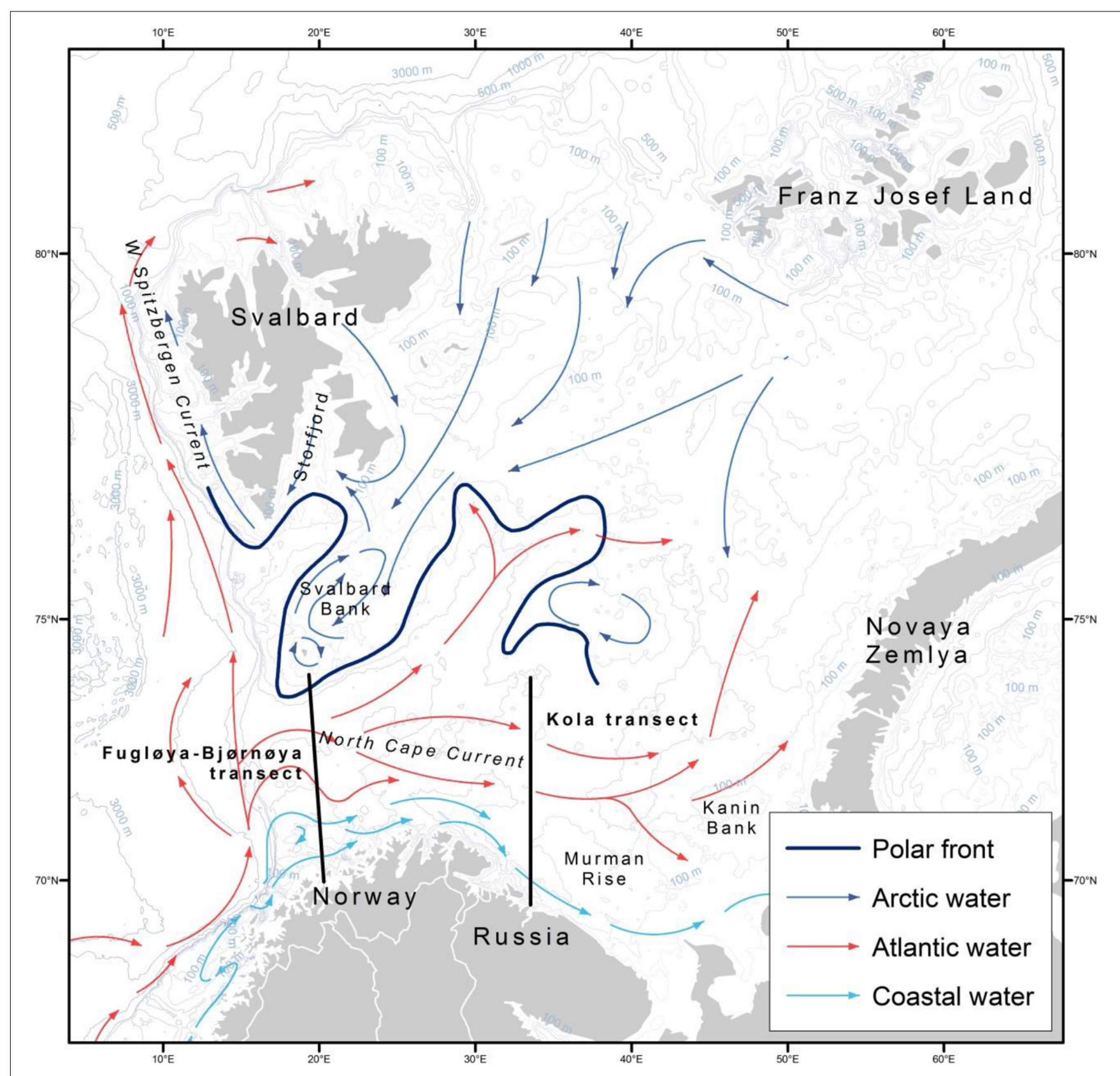

FIGURE 1 | Map of the Barents Sea region with main currents and places of interest labeled. Modified, with permission, from Stiansen and Filin (2007).

and fish stocks with the structure of the overwintering euphausiid assemblages.

\section{DEFINITION OF BARENTS SEA SUB-REGIONS}

In order to define regions with similar oceanographic characteristics, four variables (temperature and salinity values at 10 and $125 \mathrm{~m}$ ) were extracted from the NOAA climatic atlas of the Barents Sea (Matishov et al., 1998). These depths were chosen to include as many stations as possible, but also to represent areas below the surface and Arctic water layers. A total of 19,270 data points were available for the period of this study and the four variables in question were standardized to have means equal to 0 and variances equal to 1 . Each pair of stations had an oceanographic distance (inter-station similarity value) based on their standardized values of these four oceanographic variables, as well as a geographic distance, which was similarly standardized. An overall inter-station distance was then computed, combining the oceanographic and geographic distances so that the resultant groups would be more contiguous geographically. A k-means cluster analysis of these combined distances, using 20 random starting points, yielded five distinct groups, consisting of four main groups with a clear interpretation and a fifth group split 
between the far north and far south containing only a few stations. The k-means clustering algorithm is suitable for large data sets like this one, but different numbers of groups need to be considered and in each case many random starting points - for example, see Greenacre and Primicerio (2013; Chapter 8). To assign our 10,357 krill sampling stations to one of the groups, each of the stations was assigned to the most common region of the 150 geographically nearest oceanographic stations.

\section{LONG-TERM PATTERNS IN COMMUNITY STRUCTURE}

Euphausiid sampling was uneven over the regions across the years (See Supplementary Material). This sampling bias was partly corrected for by reweighting the data to agree with the overall proportion of samples in each region across the whole time period. For example, $23.8 \%$ of the samples were collected in region 1 . In 2009 only $15.9 \%$ of the samples were obtained in region 1, indicating the region was "under-sampled" relative to the longterm percentage. The total abundance values in this region for this year, therefore, were scaled up by a factor of (23.8/15.9). Each value in each year and each region were reweighted so that values across years were comparable. Unfortunately, nothing could be done about years in which no samples were taken in a given region, so a certain level of sampling bias still exists.

To investigate long-term patterns in community structure, data were aggregated to form a table of yearly abundances for the four species for the study period. Correspondence analysis (CAsee, for example, Greenacre, 2007; Greenacre and Primicerio, 2013) was used to visualize the data in the form of a biplot, showing differences in relative abundances of the four species among regions and among years. Each year of sampling was also plotted on the biplot for each region.

\section{ECOLOGICAL DRIVERS OF EUPHAUSIID ABUNDANCE}

General additive model (GAM) analyses were conducted to find the best descriptors of total euphausiid population size by region from the time series and to diagnose possible nonlinear relationships. The models were then parameterized and estimated by multiple regression (MR). The descriptor variables entering the model were the North Atlantic Oscillation (NAO) index [winter and summer principal component (PC)-based, Climate Analysis Section, NCAR, Boulder, USA, Hurrell et al. (2003)], the temperature anomaly from the Kola Transect (Stations 3-7, an oceanographic and biological transect run continuously for more than 100 years from the Russian coast to $74^{\circ} \mathrm{N}$ latitude roughly along the $33^{\circ} 30^{\prime}$ E meridian, Orlova et al., 2010b), and stock sizes (for the entire Barents Sea) of capelin (Orlova et al., 2013), herring (Toresen and Østvedt, 2000), and cod, as well as 0+ year cod, $0+$ year haddock (both only from 1980 onwards), and 1-3+ year cod (ICES, 2012). Fish and euphausiid abundances were natural$\log (x+1)$-transformed before entering the statistical analyses. The best combinations of variables in the model were selected for each region based on the Akaike Information Criterion (AIC). Relationships between the variable and log-euphausiid abundance were tested with GAM, and those that were not linear appeared to be quadratic. In this case both the log-variable and its square were entered into the subsequent MR analysis to estimate the parametric model. Total variance explained was calculated, and, when relationships were linear, a quantitative relationship between the variable and euphausiid densities was determined (i.e., what percentage change in euphausiid abundance was associated with a standardized unit change in temperature or fish abundance).

Because of the significance of advection in general in the Barents Sea (Hunt et al., 2013), and the suggestion that boreal krill species have a larger role in the pelagic food web in the last two decades (Dalpadado et al., 2012; Orlova et al., 2013), we developed a euphausiid "advection index," which was in fact suggested by the second ordination axis of the CA. This index is expressed as:

(M. norvegica + T. longicaudata $) /($ Total euphausiid abundance $)$

We conducted similar GAM and MR modeling as described above in an attempt to explain variation in the log of the advection index by climatic and predator variables. In addition, since CA results suggested that the primary axis of discrimination among years was explained by abundance of $T$. inermis vs. $T$. raschii, we ran the same GAM and MR regression analyses on the log of the ratio T. inermis/T. raschii.

\section{RESULTS}

\section{SAMPLE DOMAIN AND IDENTIFICATION OF HYDROGRAPHICAL SUB-REGIONS IN THE BARENTS SEA}

Between 1952 and 2009, up to 414 samples per year (mean $194 \mathrm{y}^{-1}$ ) were collected and processed, and a total of 10,357 euphausiid samples were analyzed for total abundance (Table S1). Of these 3912 contained data on species composition of euphausiids (Table S2). No samples were available for 1958, 1963, and 1991. The k-means cluster analysis of oceanographic data (temperature and salinity at 10 and $125 \mathrm{~m}$, i.e., four data points per station) combined with geographical proximity among data points revealed five distinct zones (Figure 2). These regions conform roughly to water mass locations and definitions from Ingvaldsen and Loeng (2009) (Figure S1), although local mixing, warming, and cooling processes must be considered. Region 1 is the coastal region from approximately the Norwegian-Russian border and eastward, bordered on the north by the Atlantic inflow. This sector is characterized by the Norwegian Coastal Current, and is largely restricted to the shallow waters over the Murman Rise and North Kanin Bank to the east. Region 2 is the area north of the average position of the Polar Front, and waters here are of Atlantic origin, after it is cooled and mixed in the southern Barents Sea (southern area), or of Arctic origin but underlain by warmer transformed Atlantic Water (northern area). It is bounded on the south by the inflowing Atlantic water, and also includes the Svalbard Bank and Storfjord areas in the west. Region 3 is a highly variable, disjoint collection of sample locations in the far south and far north. These areas are characterized by similar temperature and salinity values, but the fresher water at the surface is probably from different sources, most likely from either riverine input (south) or ice melt (north). Since it is not a natural region and contained few euphausiid sampling stations (Table 1), we conducted few analyses of biological data from this zone. Region 4 represents the Atlantic Water inflow and is restricted to deeper 


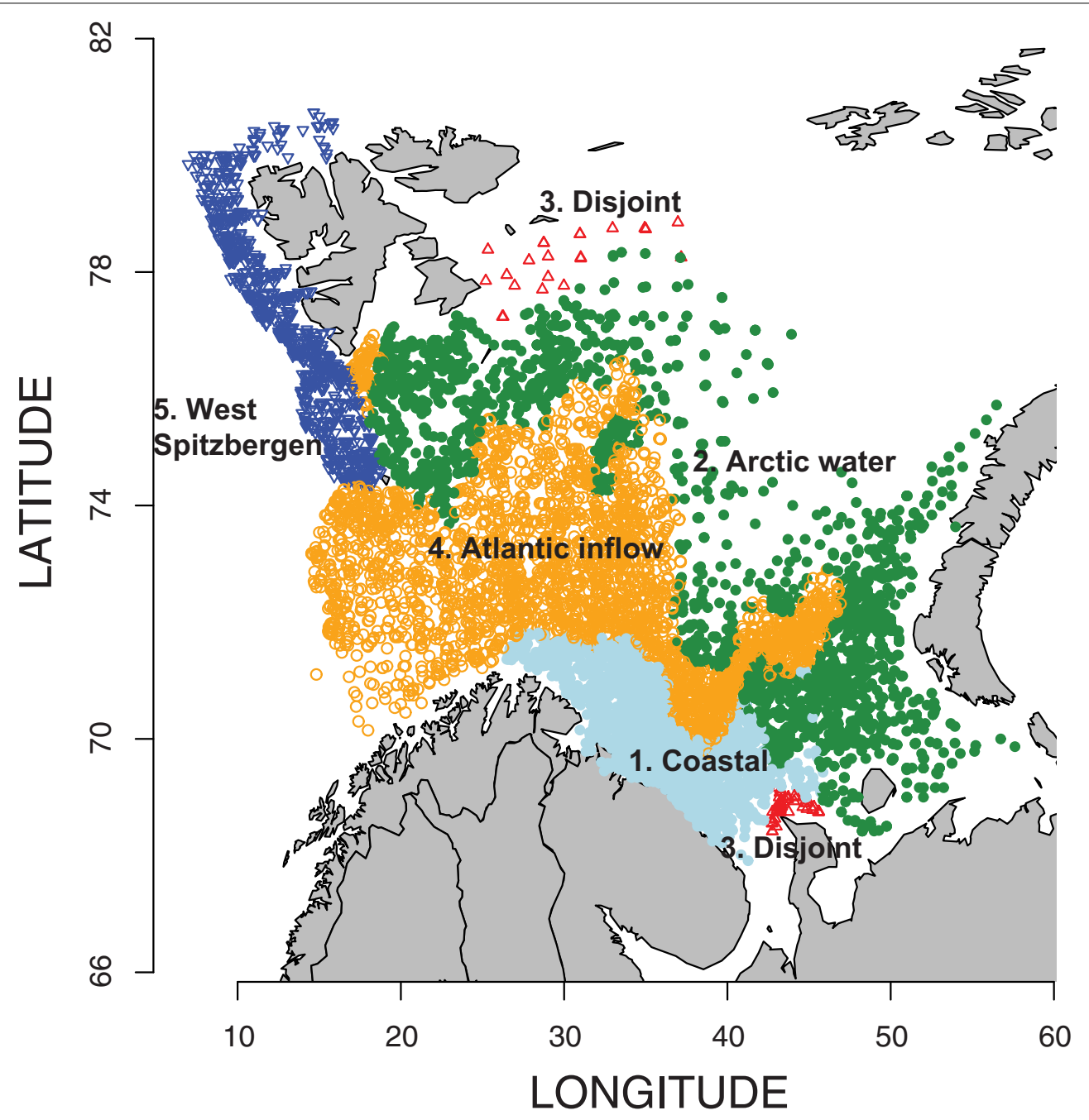

FIGURE 2 | Location of 10,357 euphausiid sampling stations in the Barents Sea related to oceanographic parameters-graybluish, Coastal waters; green, Arctic waters; red, disjoint

(excluded from analysis); orange, Atlantic waters; and blue, West Spitsbergen waters (for details-see Section “Results").

Table 1 | Number of stations (percentage of total in parentheses) for each region where total euphausiid abundance was determined (Samples for total) and where species composition was determined (Samples for species).

\begin{tabular}{lcccc}
\hline Region & Samples for total & Samples for species & Temperature $\left({ }^{\circ} \mathbf{C}\right)$ & Salinity \\
\hline Coastal & $2468(23.8 \%)$ & $1073(27.4 \%)$ & $3.7(1.2) / 3.3(1.0)$ & $34.5(0.17) / 34.7(0.11)$ \\
Arctic Water & $2695(26.0 \%)$ & $1251(32.0 \%)$ & $1.6(1.8) / 1.6(1.3)$ & $34.4(0.32) / 34.8(0.10)$ \\
Disjoint & $80(0.8 \%)$ & $36(0.9 \%)$ & $2.3(2.4) / 2.5(1.9)$ & $33.4(0.5) / 34.5(0.12)$ \\
Atlantic inflow & $4053(39.1 \%)$ & $1222(31.2 \%)$ & $3.4(1.5) / 3.0(1.3)$ & $34.8(0.23) / 34.9(0.1)$ \\
W Spitzbergen & $1061(10.2 \%)$ & $330(8.4 \%)$ & $0.2(1.6) / 1.2(1.2)$ & $34.2(0.3) / 34.7(0.09)$ \\
\hline
\end{tabular}

Total

10,357

3912

See Supplementary Material for information on distribution of this sampling by region for each year of the time series. Region assignment was made following k-means cluster analysis on oceanographic data and geographic proximity. Mean (standard deviation) temperature and salinity of the 10/125 $\mathrm{m}$ depths from each zone are also included. 
areas in the north and east, bounded on the north by the Polar Front and in the south by the Coastal Current and shallow waters. Region 5 is the West Spitsbergen Current area, characterized by cooled Atlantic Water north of Bear Island and along the west and northwest of the Svalbard/Spitsbergen Archipelago (Figure 2).

\section{LONG-TERM PATTERNS IN COMMUNITY STRUCTURE}

Community compositions of euphausiids were separated by the CA along two axes explaining over 99\% of the inter-regional variation (Figure 3). Most of the variability (94\%) was explained by the continuum between Thysanoessa inermis and T. raschii (horizontal axis), whereas the relative abundance of $T$. longicaudata and Meganyctiphanes norvegica described the second axis. The centers of gravity for each region, when plotted on these axes, revealed two regions (1 and 2) most strongly influenced by $T$. raschii, two regions ( 3 and 5 ) by $T$. inermis, and one (Region 4) that typically had a relatively strong contribution of T. longicaudata and M. norvegica (Figure 3).

When factors defining "euphausiid space" are examined in greater detail for each region (Figure 4), interannual variability in species composition becomes clear. The coastally influenced Region 1 fluctuates among years with high T. raschii abundances (1964, 1968-1982, and 2005), and several years in the early 1960s and late 2000s that were dominated by T. inermis (Figure 4). Warmer years (indicated by seawater-temperature anomalies, Figure 1.1.1 in Orlova et al., 2010a) were usually mapped in the top part of the figure, indicating the influence of boreal taxa $T$. longicaudata and M. norvegica. In the modified Arctic waters of Region 2, years were described nearly exclusively by the relative abundance of $T$. inermis and $T$. raschii, with little influence of the year's climatology. The only years with significant contributions of T. longicaudata and M. norvegica were the warm 1954, and 1983, and moderate to cold 1953 and 1956 (Figure 4). The Atlantic inflow region of the Barents Sea (Region 4) was dominated by the two advected boreal taxa and T. inermis in nearly all years. In the warmest years (1954, 1989, and most of the 2000s) there is a strong component of T. longicaudata and $M$. norvegica evident (Figure 4). A similar pattern was observed in Region 5 along the West Spitsbergen Current, although this region was sampled in fewer years when $T$. longicaudata and $M$. norvegica were, again, relatively less abundant during cold years (Figure 4).

\section{ECOLOGICAL DRIVERS OF EUPHAUSIID ABUNDANCE}

GAM, followed by MR, identified the two factors best accounting for variation in euphausiid abundance in each region (except for Region 3, which was discontinuous and had few samplings). The quadratic of the NAO winter PC-values and the quadratic of total cod densities taken together explained 37.4\% (adjusted $\mathrm{R}^{2}$ ) of the total variability in euphausiid abundance in Region 1. Both quadratic relationships were concave, with an increase in euphausiid abundance with increasing values of NAO (winter) or cod, up to values just around 0 and $1400 \times 10^{9} \mathrm{~g}$ (k tons), respectively, beyond which euphausiid abundance decreased with increasing values. In Region 2, linear effects of the Kola temperature anomaly and the log-abundance of capelin explained $64.4 \%$ of the total euphausiid variability (Table 2 ). Since the relationships were linear, it was possible to calculate the quantitative responses of euphausiid abundances to each factor. Each 0.1 increase in the Kola anomaly resulted in a $9.7 \%$ increase in euphausiid abundance; and euphausiids declined by $2.9 \%$ per $10 \%$ increase in capelin biomass.

As in Region 2, euphausiid abundance in Region 4 was linearly related to the Kola temperature anomaly and capelin. These two factors explained over $30 \%$ of the total variability in euphausiid abundance, which increased by $6.5 \%$ for each 0.1 increase in the Kola anomaly, and decreased by $2 \%$ for each $10 \%$ increase in capelin biomass. The combination of the Kola anomaly and the quadratic relationship with total cod abundance provided similar explanatory power for euphausiid abundance (29.8\%), again with a concave relationship between euphausiid abundance and cod biomass. A similar trend also observed for Region 5, where the linear effect of the Kola temperature anomaly $(6.5 \%$ for each 0.1 increase) and the quadratic relationship with total cod biomass explained $35.3 \%$ of total variability. Here, euphausiid abundance increased linearly with cod stock up to approximately $1400 \times 10^{9} \mathrm{~g}$, followed by a negative relationship at higher cod biomasses (Table 2 ).

Modeling efforts using species composition instead of total abundance also yielded significant effects of climate and/or predator populations. The factors explaining significant variation, however, were different in different regions. Where they were significant, temperature was positively related to euphausiid abundance and predator abundance was negatively related to euphausiid abundance. The Kola temperature anomaly explained only a modest $8.8 \%$ of the variability in the log-ratio of $T$. inermis:T. raschii in Region 1, but in combination with cod abundance ( $\log$ ) explained nearly half the variability in the ratio in Region 4 (Table 3). In Region 5, capelin abundance (log) alone explained nearly $40 \%$ of the variability in the log ratio (Table 3 ). Effects on the ratio were positive for the Kola temperature anomaly (increase in anomaly resulted in an increase in T. inermis/T. raschii $\log$ ratio), but the association was negative for both species of predators. No significant relationships were found in Region 2.

Both the Kola temperature anomaly and capelin abundance strongly influenced the advection index in Region 1, explaining over $19 \%$ of the variability (Table 3). Climatic effects were statistically significant, but small, in Regions 2, 4, and 5 (explaining between 6.5 and $10.5 \%$ of the variability), and here it was either the summer or winter component of the NAO that had the greatest explanatory power (Table 3 ). Predators had no statistically significant impact on the advection index in these regions. Again, the significant climatic anomalies were positively related to the advective index, whereas capelin abundance in Region 1 was negatively related.

\section{DISCUSSION}

The Barents Sea is widely acknowledged to exhibit considerably regional variability in hydrography (e.g., water mass properties, ice cover), community structure of biotic components, and impacts of advection (e.g., Sakshaug et al., 2009; Stiansen et al., 2009). Despite such variability, the Barents Sea (including its Arctic and sub-Arctic parts) is often considered as a single ecosystem when exploring impacts of predation and climatic variability on zooplankton and fish (e.g., Hjermann et al., 


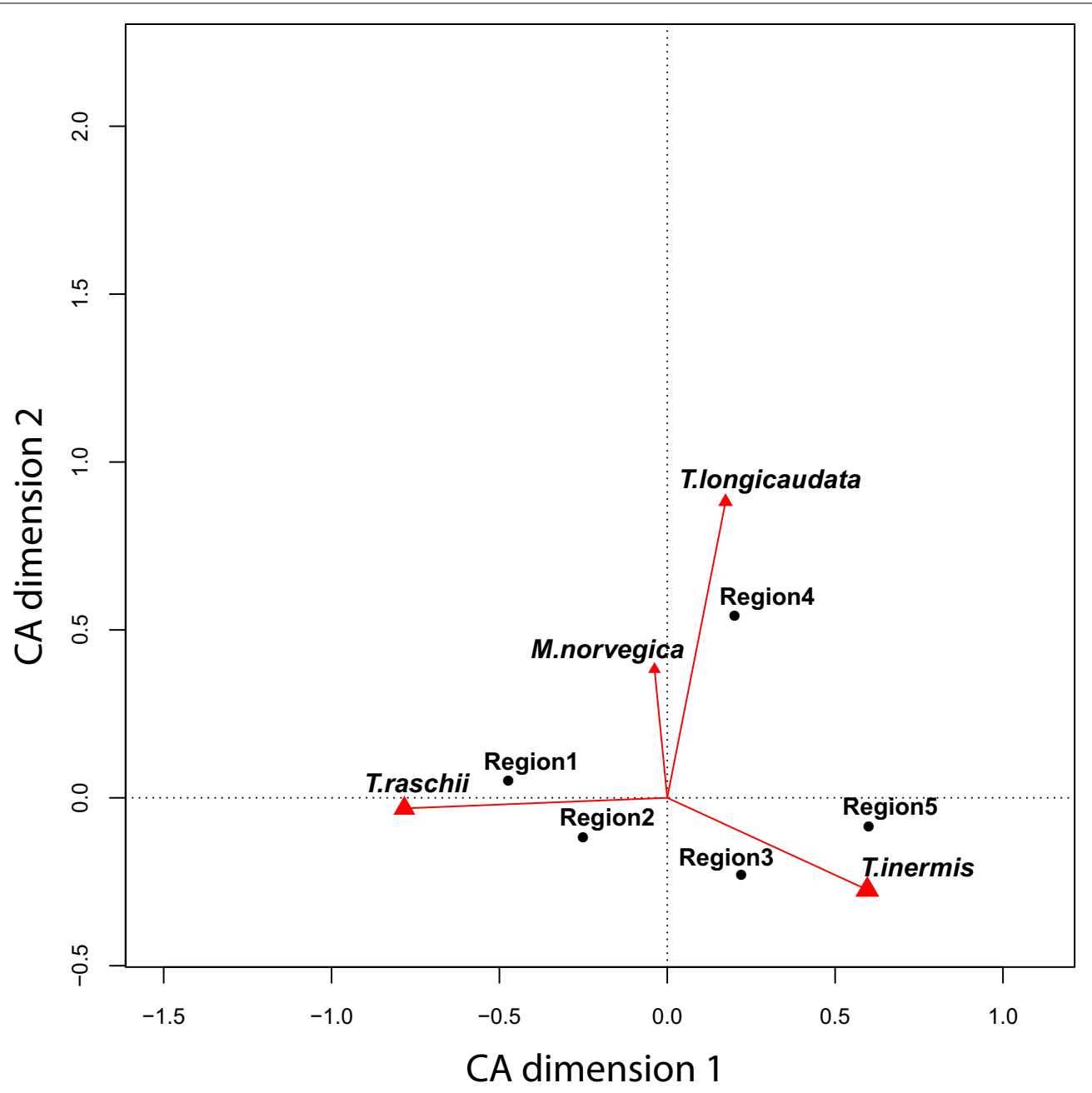

FIGURE 3 | Correspondence Analysis (CA) biplot for all stations and years. The two axes explain more than $99 \%$ of the total variability among regions. Black points represent the center of mass for each region, and the vectors indicate the strength (length) and direction of positive loadings of these species (T., Thysanoessa; M, Meganyctiphanes). The horizontal axis is represented by a continuum between $T$. raschii (left) and T. inermis (right), whereas the vertical axis is largely described by the contribution of the M. norvegica and T. longicaudata. Whereas Region 5 is strongly characterized by $T$. inermis, T. raschii is more dominant in Regions 1 and 2. Region 4 has a high component of the taxa contributing to the vertical axis.
2004, 2007; Eriksen and Dalpadado, 2011; Dalpadado et al., 2012; Johannesen et al., 2012). Our results indicate that, mechanistically, the Barents Sea should be viewed regionally and not as one ecosystem. We provide estimates of quantitative links between climate, predation, and the structure of euphausiid assemblages, which are valuable for evaluation of ecosystem resilience and the development of management strategies in a changing Arctic.

\section{LONG-TERM AND SPATIAL CHANGES IN EUPHAUSIID COMMUNITY}

Thysanoessa inermis and T. raschii comprise the majority of the euphausiid stocks in the Barents Sea, and there is spatial segregation in their distributions with T. inermis being more abundant in the west and south, an $T$. raschii more restricted to colder waters of the north and east (e.g., Drobysheva, 1994). Further, T. raschii populations expand westward during cooler years. An increase in T. inermis during warm years is responsible for an overall increase in euphausiid abundance in the Barents Sea (Drobysheva, 1994; Orlova et al., 2010b, 2013; Dalpadado et al., 2012). We found that Coastal and Arctic regions ( 1 and 2 ) fluctuated primarily between dominance by $T$. inermis (warmer years) and T. raschii (colder years) (Figure 4). Furthermore, T. inermis was always the predominant euphausiid in the Atlantic inflow and West Spitzbergen regions (4 and 5), with variable importance of advected $T$. longicaudata and $M$. norvegica (Figure 3). This finding is already more complex than the east-west segregation discussed above. Northward advection of boreal species, T. inermis as well as T. longicaudata and Meganctiphanes norvegica, is more intense during warm years (e.g., Drobysheva et al., 2003; Zhukova et al., 2009; Buchholz et al., 2010, 2012), an effect particularly evident since 2000 in Regions 1, 4, and 5 (Figure 4, Table 3). In these recent years, warmer conditions (e.g., Walczowski and Piechura, 2006) have led to a more reliable input of these taxa to some areas of the Barents Sea and west Spitzbergen, perhaps also 

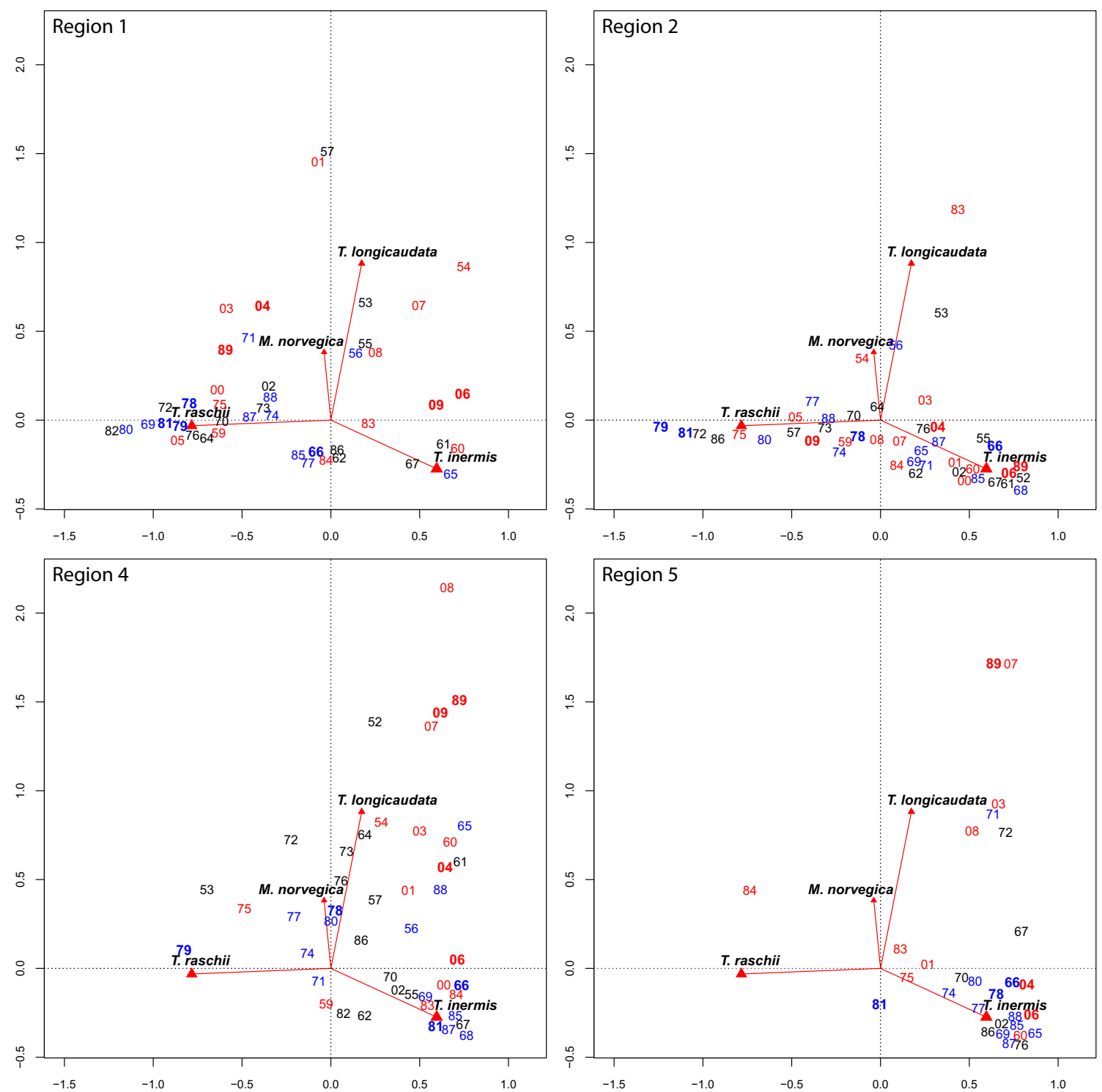

FIGURE 4 | Sampling years (labeled by last two numerals) for each of Regions 1, 2, 4, and 5 superimposed on the CA biplot for the entire data series. Years in dark bold red are very warm years, years in red are warm, years in black are normal, light blue

contributing to high stock abundance and broad distribution of Atlantic cod in the Barents Sea (Orlova et al., 2013). Thus, examining patterns in hydrographically defined regions allowed us to better understand variability in spatial patterns in euphausiids over time.

These findings indicate greater complexity than the generally accepted pattern (see above) of euphausiid distributions in the Barents Sea, and the influence of thermal conditions on species composition. Climatic state certainly influences advection of T. longicaudata and M. norvegica into Regions 4 and 5, but strong advection years based on appearance of boreal migrants in Region 1 (e.g., 1953-1957, 1971, 2000) are not well explained by climatology. The dual nature of $T$. inermis, as a resident reproducing in the Barents Sea and as a boreal migrant imported from the Norwegian Sea, also complicates matters, and likely limits the value of the advective index tested here. Climatic conditions and predator abundances generally had low explanatory power (low $R^{2}$ values) for this index, except in Region 1 (Table 3). Even in a region most frequently influenced by advection (Region 4), relative amounts of $T$. raschii and $T$. inermis vary more or less independently of climatic condition, but are strongly negatively related to cod abundance (Tables 2, 3). It is possible that different amounts of resident $T$. inermis may buffer the system against low advection years (high resident fraction), or may enhance the apparent impact of low advection years (low resident fraction), in determining where on the T. raschii- T. inermis continuum a 
Table 2 | Results of the best multiple regressions and general additive models (GAM) describing impact of climatic and predator abundances [log(total Barents Sea stock size)] on euphausiid abundances [log(abundance $\left.\left.\mathrm{m}^{-3}\right)\right]$ by region.

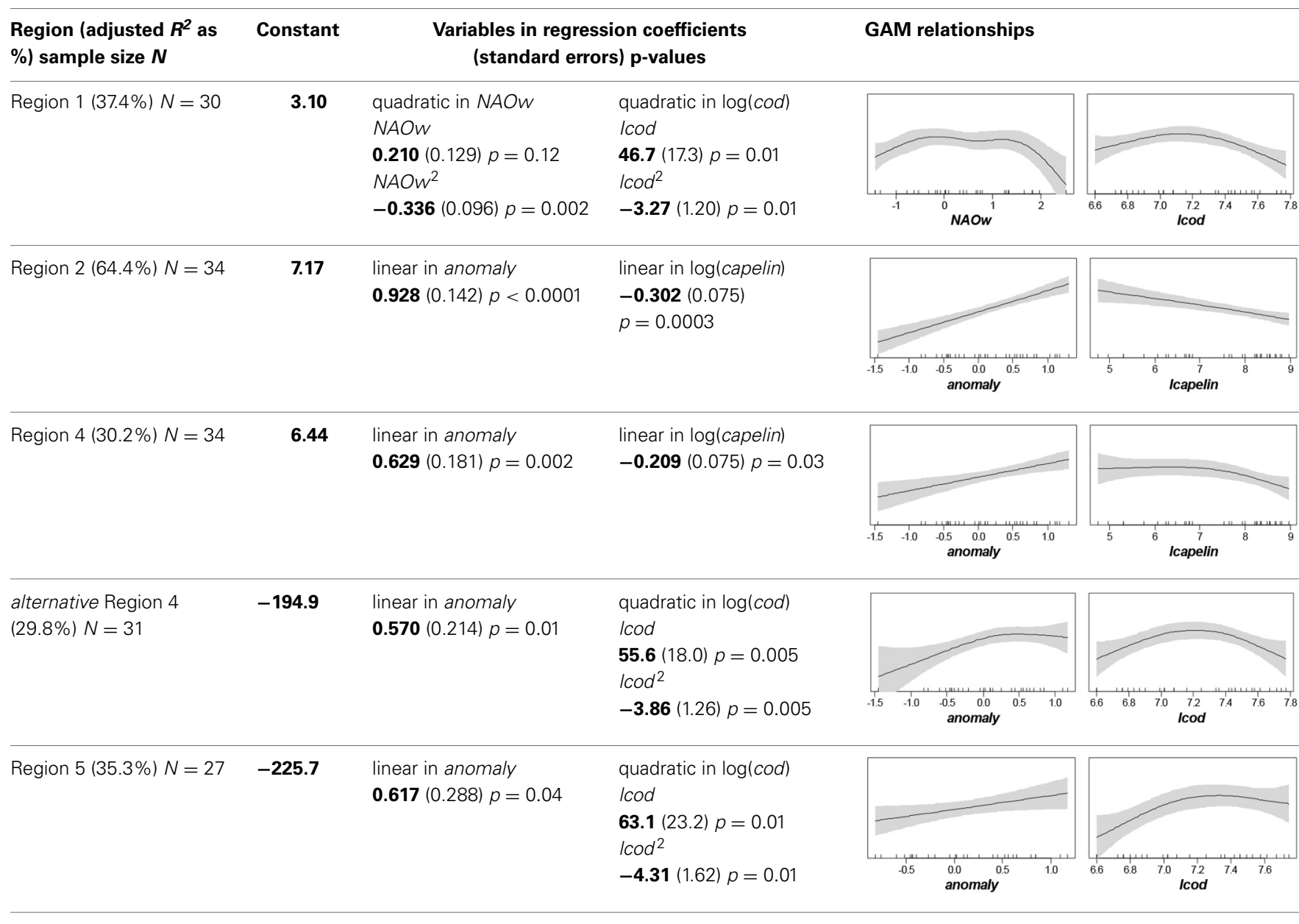

Two models with similar explanatory power are presented for Region 4. The left column contains total sample size (number of years) and the adjusted $R^{2}$ of the multiple regression model. Constants and coefficients along with p-values are presented in the third column, whereas GAM relationships with $95 \%$ confidence intervals (shaded) are presented on the right. "anomaly" = Kola Transect temperature anomaly; "NAOW" = North Atlantic Oscillation Index winter value.

particular year will lie. But for now, there is no way of differentiating resident from advective fractions. So while climatic conditions are clearly important in determining euphausiid community structure, yet-to-be-determined interacting effects of advection, redistribution by local processes, and predator pressure also play important roles.

IMPACTS OF CLIMATE AND PREDATION ON EUPHAUSIID ABUNDANCE Climate, and temperature in particular, has been linked with euphausiid abundance and biomass in the Barents Sea. Specifically, increased temperatures such as those observed since the mid-1990s, have a positive correlation with euphausiid biomass (Dalpadado et al., 2003, 2012; Zhukova et al., 2009; Orlova et al., 2010b). Certainly much of the impact of climate on euphausiids is through supply of both juvenile and adult stages to different regions of the Barents Sea. Climate variability, however, may also affect the timing and quantity for food for euphausiids during the growing season, thus contributing to growth and overwintering success via bottom-up forcing. We have no data on food availability, however. Our results show a strong coupling of climatic conditions with euphausiid abundances on a regional basis, although these results vary qualitatively and quantitatively among regions. The temperature anomaly at the Kola Transect was positively and linearly correlated with euphausiid abundance in Regions 2, 4, and 5 (Table 2). The quantitative effect was strongest in the Arctic Water region (Region 2), where a $9.7 \%$ increase in abundance was associated with an increase of 0.1 in the anomaly. Similar 6.5 and $6.4 \%$ increases were recorded in Regions 4 and 5, respectively, but surprisingly, no relationship was observed between the Kola anomaly and euphausiids in Region 1, which contains part of the Transect (Table 2). Instead, euphausiid abundance in Region 1 showed a quadratic relationship with the NAO, a positive correlation when the winter NAO index was below 0.2 and a sharp decline in abundance when the NAO index was above 1.

The Kola Transect generally reflects conditions over the entire Barents Sea, and has been correlated with the NAO and regional ecology (Ottersen and Stenseth, 2001), at least until recent years 
Table 3 | Results of the best multiple linear regressions describing impact of climatic and predator abundances (log) on the log of the ratio T. inermis/T. raschii (upper panel) and the log of the "advective index" (lower panel) by region.

\begin{tabular}{|c|c|c|c|c|}
\hline $\begin{array}{l}\text { Region (adjusted } R^{2} \text { as } \\
\% \text { ) sample size } N\end{array}$ & Constant & \multicolumn{2}{|c|}{$\begin{array}{l}\text { MODELING log(Th_in/Th_ra) } \\
\text { Variables in regression coefficients } \\
\text { (standard errors) p-values }\end{array}$} & Interpretation \\
\hline Region 2 & - & \multicolumn{2}{|c|}{-} & - \\
\hline Region 5 (38.6\%) $N=22$ & -11.53 & \multicolumn{2}{|c|}{$\begin{array}{l}\text { linear in log(capelin) } \\
\mathbf{- 1 . 1 4}(0.30) p=0.001\end{array}$} & $\begin{array}{l}10.3 \% \text { decrease } T h \_i n / T h \_r a \text { per } 10 \% \\
\text { increase in capelin }\end{array}$ \\
\hline Region $1(19.2 \%) N=24$ & 0.630 & $\begin{array}{l}\text { linear in anomaly } \\
\mathbf{0 . 7 6 9}(0.372) p=0.05\end{array}$ & $\begin{array}{l}\text { linear in } \log (\text { capelin) } \\
-\mathbf{0 . 5 0 1}(0.251) p=0.05\end{array}$ & $\begin{array}{l}8.0 \% \text { increase in Advec.Index per } 0.1 \\
\text { increase in anomaly } \\
4.7 \% \text { decrease in Advec.Index per } \\
10 \% \text { increase in capelin }\end{array}$ \\
\hline Region $2(9.8 \%) N=43$ & -4.030 & \multicolumn{2}{|c|}{$\begin{array}{l}\text { linear in NAOs } \\
\mathbf{0 . 4 7 4}(0.224) p=0.04\end{array}$} & $\begin{array}{l}4.8 \% \text { increase in Advec.Index per } 0.1 \\
\text { increase in NAOs }\end{array}$ \\
\hline Region $4(6.5 \%) N=43$ & -2.123 & \multicolumn{2}{|c|}{$\begin{array}{l}\text { linear in NAOw } \\
\mathbf{0 . 2 6 5}(0.134) p=0.05\end{array}$} & $\begin{array}{l}2.7 \% \text { increase in Advec.Index per } 0.1 \\
\text { unit increase in NAOW }\end{array}$ \\
\hline
\end{tabular}

["Advec. Index" = (M. norvegica + Th. longicaudata)/(total euphausiids)]. The left column contains total sample size (number of years) and the adjusted $R^{2}$ of the model. Constants and coefficients along with p-values are presented in the third column. Numerical interpretation is included in the right column. No significant regression was found for the log of T. inermis/T. raschii in Region 2. "anomaly" = Kola Transect temperature anomaly; "NAOs" and "NAOw"= North Atlantic Oscillation Index summer and winter values, respectively.

(Johannesen et al., 2012). Each year, Regions 4 and 5 receive direct influx of warm waters and the organisms advected with it, including euphausiids. It is, therefore, no surprise that warmer climatic conditions, indicating greater advection and inflow into the Barents Sea, result in a strong increase in euphausiids in these regions (Orlova et al., 2013). The strong response of euphausiid communities to increased advection in Region 2 may be due to greater inflow of $T$. inermis from the Atlantic into areas traditionally characterized by Arctic Water, which in warm years can support high growth of both Arctic and boreal taxa. Region 1's complex (quadratic) relationship with the NAO is difficult to explain, but may be related to how inflowing water is distributed among the three branches of the Atlantic inflow (North Cape Current, Figure 1) in years of different climatic condition. Region 1 is also affected by the Norwegian Coastal Current, and mixing with locally-produced waters over several shallow banks.

The length of our time-series (1952-2009) spans multiple climatic cycles, providing increased confidence that relationships between euphausiid densities and climatic state are well-founded.
The first decade of the 21st century, however, appears to be quite different from previous decades. Since 1996, the historically strong correlation between the NAO and the temperatures along the Fugløya-Bjørnøya Transect, at the southwestern opening to the Barents Sea (Figure 1), has disappeared (Johannesen et al., 2012). Further, there has been a decrease in the variability of euphausiid standing stocks, despite an increase in advection of capelin from boreal waters (Orlova et al., 2013). Euphausiid biomass was high between 2007 and 2010 despite high capelin populations (Eriksen and Dalpadado, 2011), whereas during the previous two decades both euphausiids (Eriksen and Dalpadado, 2011) and zooplankton (mostly copepod) biomass varied inversely with capelin abundance (Dalpadado et al., 2003). It is unclear whether this change in the euphausiid-capelin relationship constitutes a regime shift, but these differences can have significant impact on trophic relationships throughout the food web.

Planktivorous fish reduce the size of zooplankton populations, including those of euphausiids in the Barents Sea (e.g., Dalpadado 
and Skjoldal, 1996). This can overwhelm climatic effects when fish abundances are high (Stige et al., 2009). We found predation effects varied significantly among regions, with capelin having strong linear (negative) effects on euphausiid abundance in Regions 2 and 4 (2-3\% decrease in euphausiid abundance per $10 \%$ increase in capelin biomass), and cod having a greater role in Regions 1 and 5. Capelin are known to have strong impacts on euphausiid populations in the Barents Sea (e.g., Drobysheva, 1994; Orlova, 2002; Orlova et al., 2013), but we also found strong (high explanatory power) and complex (non-linear) relationships between cod standing stock and euphausiid abundance. Regions 1, 4, and 5 exhibited a threshold-type response curve, where increased cod biomass was positively correlated with euphausiid stock size until approximately $1400 \times 10^{9} \mathrm{~g}$ cod, when the relationship became inverse. An analogous threshold effect was noted for capelin feeding on copepods in the southern Barents Sea (Stige et al., 2009). One possible mechanism for such an effect could be the following - cod feed on capelin, which then decreases predation pressure of capelin on euphausiids (c.f. Fiksen et al., 2005). But beyond a certain level of cod biomass $\left(1400 \times 10^{9} \mathrm{~g} \operatorname{cod}\right.$ in our data) capelin abundance is no longer high enough to support the cod, and cod begin feeding on euphausiids. Climate, through its impact of advection, may also have strong, positive relationships with both cod and euphausiids. Such a response is consistent with the observations of Drobysheva (1994). The very similar cod-threshold value for each of these three regions is striking, but we so far have no mechanism explaining why this value is so consistent.

Our finding of regional differences in which fish species had the larger effect on euphausiids can be linked with seasonality in both advection and capelin feeding-migrations. Stige et al. (2009) found effects of capelin feeding along the Fugløya-Bjørnøya Transect within Region 4 in spring, whereas the effect along the Kola Transect (partly in Region 1, but also 2 and 4, Figure 1) was not felt until summer. Capelin seasonal feeding migrations begin in spring from the mainland coast and proceed in a more or less clock-wise direction through the Barents Sea (Gjøsæter, 1998), whereas advection of euphausiids (and other zooplankton) into the Barents Sea is strongest in spring (Drobysheva, 1994). Since capelin will have the strongest effects where their feeding overlaps with concentrations of advected (or resident) euphausiids, it is not to be expected that they will have significant impact in Region 5, and perhaps only limited impact in Region 4. Here, resident Atlantic cod along the Norwegian coast, and advected cod from the Norwegian Sea and up toward Svalbard would be expected to have more impact over a longer period (not just during spring peaks in inflow). This scenario is suggested by the strong negative impact of cod on euphausiid community structure in Regions 4 and 5 (Table 3). Effects of cod (and lack of strong capelin effects) in Region 1 can be explained by the different seasonality of feeding by these two fish species in this Region. Capelin only feed on euphausiids in Region 1 during their pre-spawning migrations in February-April, so will have no statistical impact on euphausiid abundance in autumn-winter. In contrast, cod consume euphausiids intensively in this area in summer (so-called "euphausiid feeding"), with consequences during the sampling period (Zatsepin and Petrova, 1939; Orlova et al., 2001).
Surprisingly, we found no strong impact of herring, or of $0+$, $1+$, and $2+$ cod and haddock. Stige et al. (2009) also found little effect of predation by herring in their studies, but the young cod and haddock stages are all known to feed on euphausiids (e.g., Ponomarenko and Yaragina, 2003; Dalpadado et al., 2009), and in fact cod largely stop feeding on euphausiids after 3 years. Our data on $0+$ age classes of cod and haddock only go back to 1980 , so this may have limited our ability to find effects during this period of strong climatic shifts.

\section{IMPLICATIONS FOR THE FUTURE BARENTS SEA PELAGIC ECOSYSTEM}

Combined impacts of climate and predatory fish explain from 30 to over $60 \%$ of the variation in euphausiid abundance on a regional basis, and these relationships were quantified in our regression models. Furthermore, impacts of these two factors on euphausiid community structure can be highly significant, and also vary regionally. Although mechanistic understanding of these relationships is not complete, these results and the growing body of literature on the topic suggest the system is dynamic, spatially segregated, and susceptible to variability in advection, fish stock size, and their interactions with climatic forcing. Thus, predictions for a future Barents Sea pelagic food-web need to reflect these complexities and the non-linear relationships inherent in the system.

Predicted shifts in capelin populations to the eastern Barents Sea (Hop and Gjøsæter, 2013) could enhance the capelin effect in the Arctic Water region (Region 2) and decrease it in Region 4 in the future. And if cod continue to increase, the impact of this (quadratic) threshold response could result in enhanced top-down control by cod over euphausiid abundance. This may make the pelagic ecosystem - now buffered by high advection of euphausiids (Orlova et al., 2013) -more susceptible to periodic crashes, particularly if other boreal planktivores (mackerel, blue whiting) also increase in abundance (Anon, 2010).

Quantification of variability in the standing stocks of zooplankton and fishes is important for understanding and management of ecosystems (Hjermann et al., 2007). Regional differences in prey/predator interactions can provide insight into ecological processes driving variability in these standing stocks. Significant quantitative effects of both climate and predation on euphausiid densities, integrated on an annual basis by sampling during winter months, can help parameterize ecosystem models testing climate and ecological change scenarios. Our results indicate that these models should be both spatially discrete and consider both annual routines of predators and their prey as well as possible lagged effects.

\section{ACKNOWLEDGMENTS}

The authors wish to thank PINRO and Russian/Soviet scientists who started and supported euphausiid investigations in the Barents Sea, making it one of the longest biological timeseries anywhere. Boris P. Manteifel initiated euphausiid investigations as food supply for commercially important fish in the Barents Sea; Tamara S. Berger and Elena A. Pavshtiks provided the methodological base for euphausiid surveys by testing appropriate sampling tools and seasons; and Svetlana S. Drobysheva and Valentina N. Nesterova organized and supported 
these investigations in 1950-1990s. We also gratefully acknowledge Chris Emblow for graphics support, and financial support from Statoil and Akvaplan-niva. Michael Greenacre's research is partially supported by grant MTM2012-37195 of the Spanish Ministry of Economy and Competitiveness. This manuscript was improved by comments from F. Buchholz.

\section{SUPPLEMENTARY MATERIAL}

The Supplementary Material for this article can be found online at: http://www.frontiersin.org/journal/10.3389/fmars. 2014.00074/abstract

\section{REFERENCES}

Abraham, C. L., and Sydeman, W. J. (2004). Ocean climate, euphausiids and auklet nesting: inter-annual trends and variation in phenology, diet and growth of a planktivorous seabird, Ptychoramphus aleuticus. Mar. Ecol. Prog. Ser. 274, 235-250. doi: 10.3354/meps274235

Anon. (2010). "Survey report from the joint Norwegian/Russian ecosystem survey in the Barents Sea August-September 2010," in IMR/PINRO Joint Report Ser, No. 4/2010 (Bergen).

Brinton, E., and Townsend, A. (2003). Decadal variability in abundances of the dominant euphausiid species in southern sectors of the California Current. Deep Sea Res II 50, 2449-2472. doi: 10.1016/S0967-0645(03)00126-7

Buchholz, F., Buchholz, C., and Weslawski, J. M. (2010). Ten years after: krill as indicator of changes in the macro-zooplankton communities of two Arctic fjords. Polar Biol. 33, 101-113. doi: 10.1007/s00300-009-0688-0

Buchholz, F., Werner, T., and Buchholz, C. (2012). First observation of krill spawning in the high Arctic Kongsfjorden, west Spitsbergen. Polar Biol. 35, 1273-1279. doi: 10.1007/s00300-012-1186-3

Coyle, K. O., Eisner, L. B., Mueter, F. J., Pinchuk, A. I., Janout, M. A., Cieciel, K. D., et al. (2011). Climate change in the southeastern Bering Sea: impacts on pollock stocks and implications for the oscillating control hypothesis. Fisheries Oceanogr. 20, 139-156. doi: 10.1111/j.1365-2419.2011.00574.x

Dalpadado, P., Bogstad, B., Eriksen, E., and Rey, L. (2009). Distribution and diet of 0-group cod (Gadus morhua) and haddock (Melanogrammus aeglefinus) in the Barents Sea in relation to food availability and temperature. Polar Biol. 32, 1583-1596. doi: 10.1007/s00300-009-0657-7

Dalpadado, P., Ingvaldsen, R. B., Stige, L. C., Bogstad, B., Knutsen, T., Ottersen, G., et al. (2012). Climate effects on Barents Sea ecosystem dynamics. ICES J. Mar. Sci. 69, 1303-1316. doi: 10.1093/icesjms/fss063

Dalpadado, P., Ingvaldsen, R., and Hassel, A. (2003). Zooplankton biomass variation in relation to climatic conditions in the Barents Sea. Polar Biol. 26, 233-241. doi: 10.1007/s00300-002-0470-z

Dalpadado, P., and Mowbray, F. (2013). Comparative analysis of feeding ecology of capelin from two shelf ecosystems, off Newfoundland and in the Barents Sea. Progr. Oceanogr. 114, 97-105. doi: 10.1016/j.pocean.2013.05.007

Dalpadado, P., and Skjoldal, H. R. (1996). Abundance, maturity and growth of the krill species Thysanoessa inermis and T. longicaudata in the Barents Sea. Mar. Ecol. Progr. Ser. 144, 175-183. doi: 10.3354/meps 144175

Dorman, J. G., Powell, T. M., Sydeman, W. J., and Bograd, S. J. (2011). Advection and starvation cause krill (Euphausia pacifica) decreases in 2005 Northern California coastal populations: implications from a model study. Geophys. Res. Lett. 38:L04605. doi: 10.1029/2010GL046245

Drinkwater, K. F. (2006). The regime shift of the 1920s and 1930s in the North Atlantic. Progr. Oceanogr. 68, 134-151. doi: 10.1016/j.pocean.2006.02.011

Drobysheva, S. S. (1982). Degree of Isolation of Thysanoessa inermis (Krøyer) and T. raschii (M. Sars, 1864) (Crustacea, Euphausiacea) Populations in the Southern Barents Sea. ICES C.M.1982/L:19. (Copenhagen: International Council for the Exploration of the Sea (ICES)), 21.

Drobysheva, S. S. (1994). Euphausiidae of the Barents Sea and their Role in the Formation of Commercial Bioproduction. Murmansk: PINRO Press (in Russian)

Drobysheva, S. S., Nesterova, V. N., Nikiforov, A. G., and Zhukova, N. G. (2003). Role of warm water component in formation of euphausiids local aggregations in the southern Barents Sea. Voprosy Rybolovstva 4, 209-216 (in Russian).

Eriksen, E., and Dalpadado, P. (2011). Long-term changes in krill biomass and distribution in the Barents Sea. Are the changes mainly related to capelin stock size and temperature conditions? Polar Biol. 34, 1399-1409. doi: 10.1007/s00300011-0995-0

Fiksen, Ø., Melle, W., Torgersen, T., Breien, M. T., and Klevjer, T. A. (2005). Piscivorous fish patrol krill swarms. Mar. Ecol. Progr. Ser. 299, 1-5. doi: $10.3354 /$ meps 299001

Gjøsæter, H. (1998). The population biology and exploitation of capelin (Mallotus villosus) in the Barents Sea. Sarsia 88, 261-273.

Gómez-Gutiérrez, J., Palomares-García, R., and Gendron, D. (1995). Community structure of the euphausiid populations along the west coast of Baja California, Mexico, during the weak ENSO 986-1987. Mar. Ecol. Prog. Ser. 120, 41-51. doi: $10.3354 /$ meps 120041

Greenacre, M. (2007). Correspondence Analysis in Practice, 2nd Edn. Boca Raton, FL: Chapman \& Hall/CRC. doi: 10.1201/9781420011234

Greenacre, M., and Primicerio, R. (2013). Multivariate Analysis of Ecological Data. Madrid: BBVA Foundation. Available online at: www.multivariatestatistics.org

Hjermann, D. Ø., Bogstad, B., Eikeset, A. M., Ottersen, G., Gjøsæter, H., and Stenseth, N. C. (2007). Food web dynamics affect Northeast Arctic cod recruitment. Proc. R. Soc. Lond. B 274, 661-669. doi: 10.1098/rspb.2006.0069

Hjermann, D. Ø., Ottersen, G., and Stenseth, N. C. (2004). Competition among fishermen and fish causes the collapse of the Barents Sea capelin. Proc. Natl. Acad. Sci. U.S.A. 101, 11679-11684. doi: 10.1073/pnas.0402904101

Hop, H., and Gjøsæter, H. (2013). Polar cod (Boreogadus saida) and capelin (Mallotus villosus) as key species in marine food webs of the Arctic and the Barents Sea. Mar. Biol. Res. 9, 878-894. doi: 10.1080/17451000.2013.775458

Hunt, G. L., Blanchard, A. L., Boveng, P., Dalpadado, P., Drinkwater, K., Eisner, L., et al. (2013). The Barents and Chukchi Seas: comparison of two Arctic shelf ecosystems. J. Mar. Syst. 109/110, 43-68. doi: 10.1016/j.jmarsys.2012.08.003

Hunt, G. L., Stabeno, P., Walters, G., Sinclair, E., Brodeur, R. D., Napp, J. M., et al. (2002). Climate change and control of the southeastern Bering Sea pelagic ecosystem. Deep Sea Res. II 49, 5821-5853. doi: 10.1016/S0967-0645(02)0 0321-1

Hurrell, J. W., Kushnir, Y., Ottersen, G., and Visbeck, M. (eds.). (2003). The North Atlantic oscillation: climate significance and environmental impact. Geophys. Monogr. Ser. 134, 279

ICES (International Council for Exploration of the Seas). (2012). Report of the Arctic Fisheries Working Group 2012 (AFWG). ICES CM 2012/ACOM:05, ICES Headquarters, Copenhagen.

Ingvaldsen, R., and Loeng, H. (2009). "Physical oceanography," in Ecosystem Barents Sea, eds E. Sakshaug, G. Johnsen, and K. Kovacs (Trondheim: Tapir Academic Press), 33-64.

Johannesen, E., Ingvaldsen, R. B., Bogstad, B., Dalpadado, P., Eriksen, E., Gjøsæter, H., et al. (2012). Changes in Barents Sea ecosystem state, 1970-2009: climate fluctuations, human impact, and trophic interactions. ICES J. Mar. Sci. 69, 880-889. doi: 10.1093/icesjms/fss046

Kovtsova, M. V., Antonov, S. G., and Orlova, E. M. (1989). 'Peculiarities of feeding and fatness dynamics of haddock Melanogrammus aeglefinus (L.) in the Barents Sea," in Trophic Relations of Benthic Organisms and Demersal Fishes in the Barents Sea, ed A. D. Chinarina (Apatity: Kola Science Center for USSR Academy of Science), 27-36 (in Russian).

Lindstrøm, U., Nilssen, K. T., Pettersen, L. M. S., and Haug, T. (2013). Harp seal foraging behaviour during summer around Svalbard in the northern Barents Sea: diet composition and the selection of prey. Polar Biol. 36, 305-320. doi: 10.1007/s00300-012-1260-x

Matishov, G., Zuyev, A., Golubev, A., Adrov, N., Slobodin, V., Levitus, S., et al. (1998). Climatic Atlas of the Barents Sea 1998: Temperature, Salinity, Oxygen. NOAA Atlas NESDIS 26, 1-24 + Appendices and CD. Washington, DC: US Department of Commerce.

Mehlum, F. (2001). Crustaceans in the diet of adult common and Brünnich's guillemots (Uria aalga and U. lomvia) in the Barents Sea during the breeding period. Mar. Ornithol. 29, 19-22.

Mauchline, J. (1980). The biology of mysids and euphausiids. Adv. Mar. Biol. 18, $1-677$.

Nilssen, K. T., Haug, T., Potelov, V., and Timoshenko, Y. K. (1995). Feeding habits of harp seals (Phoca groenlandica) during early summer and autumn in the northern Barents Sea. Pol. Biol. 15, 485-493. doi: 10.1007/BF00237462

Orlova, E. L., Boitsov, V. D., and Nesterova, V. N. (2010a). The Influence of Hydrographic Conditions on the Structure and Functioning of the Trophic Complex Plankton-Pelagic Fishes-Cod. PINRO. Murmansk: Murmansk Printing Company. 
Orlova, E. L., Dolgov, A. V., Renaud, P. E., Boitsov, V. D., Prokopchuk, I. P., and Zashihina, M. V. (2013). Structure of the macroplankton-pelagic fishcod trophic complex in a warmer Barents Sea. Mar. Biol. Res. 9, 851-866. doi: 10.1080/17451000.2013.775453

Orlova, E. L., Nesterova, V. N., and Dolgov, A. V. (2001). Euphausiids and their role in feeding of Arcto-Norwegian cod (80-90th). Voprosy Rybolovstva 2, 86-103 (in Russian).

Orlova, E. L., Ushakov, N. G., Nesterova, V. N., and Boitsov, V. D. (2002). Food supply and feeding of capelin (Mallotus villosus) of different size in the central latitudinal zone of the Barents Sea during intermediate and warm years. ICES J. Mar. Sci. 59, 968-975. doi : 10.1006/jmsc.2002.1255

Orlova, E. L., Rudneva, G. B., Nesterova, V. N., and Yurko, A. S. (2008). On the quantitative estimation of macroplankton abundance in the Barents Sea. Izvestia TINRO 152, 186-200 (in Russian).

Orlova, E. L., Rudneva, G. B., Renaud, P. E., Eiane, K., Savinov, V. M., and Yurko, A. S. (2010b). Climate impacts on feeding and condition of capelin (Mallotus villosus) in the Barents Sea. Evidence and mechanisms from a 30-year data series. Aquat. Biol. 10, 105-118. doi: 10.3354/ab00265

Ottersen, G., and Stenseth, N. C. (2001). Atlantic climate governs oceanographic and ecological variability in the Barents Sea. Limnol. Oceanogr. 46, 1774-1780. doi: 10.4319/lo.2001.46.7.1774

Ponomarenko, I. Y. A. (1973). The effects of food and temperature conditions on the survival of young bottom-dwelling cod in the Barents Sea. Rapp P-v Reun Cons. Int. Explor. Mer. 164, 199-207.

Ponomarenko, I. Y. A., and Yaragina, N. A. (2003). "Feeding and trophic relations. Cod in the Barents Sea ecosystem," in The Barents Sea Cod: Biology and Fisheries, 2nd Edn., ed V. N. Shleinik (Murmansk: PINRO Press), 62-113 (in Russian).

Renaud, P. E., Berge, J., Varpe, Ø., Lønne, O. J., Nahrgang, J., Ottesen, C., et al. (2012). Is the poleward expansion by Atlantic cod and haddock threatening native polar cod, Boreogadus saida? Polar Biol. 35, 401-412. doi: 10.1007/s00300011-1085-z

Sakshaug, E., Johnsen, G., Kristiansen, S., von Quillfeldt, C. H., Rey, F., Slagstad, D., et al. (2009). "Phytoplankton and primary production," in Ecosystem Barents Sea, eds E. Sakshaug, G. Johnsen, and K. M. Kovacs (Trondheim: Tapir Academic Press), 167-208.

Stiansen, J. E., and Filin, A. A. (eds.). (2007). Joint PINRO/IMR report on the state of the Barents Sea ecosystem 2006, with expected situation and considerations for management. IMR/PINRO Joint Report Series, 209.

Stiansen, J. E., Korneev, O., Titov, O., Arneberg, P. (eds.) Filin, A., Hansen, J. R., et al. (co-eds.). (2009). "Joint Norwegian-Russian environmental status 2008," in Report on Barents Sea Ecosystem Part II - Complete Report. Bergen: IMR/PINRO Joint Report Series 2009, 375.

Stige, L. C., Lajus, D. L., Chan, K.-S., Dalpadado, P., Basedow, S., Berchenko, I., et al. (2009). Climatic forcing of zooplankton dynamics is stronger during low densities of planktivorous fish. Limnol. Oceanogr. 54, 1025-1036. doi: 10.4319/lo.2009.54.4.1025
Sydeman, W. J., Bradley, R. W., Warzybok, P., Abraham, C. L., Jahncke, J., Hyrenbach, K. D., et al. (2006). Planktivorous auklet Ptychoramphus aleuticus responses to ocean climate, 2005: Unusual atmospheric blocking? Geophys. Res. Lett. 33:L22S09. doi: 10.1029/2006GL026736

Toresen, R., and Østvedt, O. J. (2000). Variation in abundance of Norwegian spring-spawning herring (Clupea harengus, Clupeidae) throughout the $20^{\text {th }}$ century and the influence of climatic variations. Fish Fisheries 1, 231-256. doi: 10.1046/j.1467-2979.2000.00022.x

Walczowski, W., and Piechura, J. (2006). New evidence of warming propagating toward the Arctic Ocean. Geophys. Res. Lett. 33:L12601. doi: 10.1029/2006GL025872

Yaragina, N. A., and Dolgov, A. V. (2009). Ecosystem structure and resilience - a comparison between the Norwegian and the Barents Sea. Deep Sea Res. II 56, 2141-2153. doi: 10.1016/j.dsr2.2008.11.025

Zatsepin, V. I., and Petrova, N. S. (1939). Feeding of fishery concentrations of cod in the southern Barents Sea (by observations in 1934-1938). Trudy PINRO 5, 1-170 (in Russian).

Zelikman, E. A. (1958). Materials on distribution and reproduction of euphausiids in the coastal zone of Murman. Trudy Murmansk Biol. Stations 4, 79-117 (in Russian).

Zelikman, E. A. (1964). On ecology of reproduction of the abundant species of Euphausiañåa in the south-eastern Barents Sea. Trudy Murmansk Mar. Biol. Inst. 6, 12-21. (in Russian).

Zhukova, N. G., Nesterova, V. N., Prokopchuk, I. P., and Redneva, G. B. (2009). Winter distributions of euphausiids (Euphausiacea) in the Barents Sea (20002005). Deep Sea Res. II 56, 1959-1967. doi: 10.1016/j.dsr2.2008.11.007

Conflict of Interest Statement: The authors declare that the research was conducted in the absence of any commercial or financial relationships that could be construed as a potential conflict of interest.

Received: 16 September 2014; accepted: 24 November 2014; published online: 06 January 2015.

Citation: Orlova EL, Dolgov AV, Renaud PE, Greenacre M, Halsband C and Ivshin VA (2015) Climatic and ecological drivers of euphausiid community structure vary spatially in the Barents Sea: relationships from a long time series (1952-2009). Front. Mar. Sci. 1:74. doi: 10.3389/fmars.2014.00074

This article was submitted to Global Change and the Future Ocean, a section of the journal Frontiers in Marine Science.

Copyright (c) 2015 Orlova, Dolgov, Renaud, Greenacre, Halsband and Ivshin. This is an open-access article distributed under the terms of the Creative Commons Attribution License (CC BY). The use, distribution or reproduction in other forums is permitted, provided the original author(s) or licensor are credited and that the original publication in this journal is cited, in accordance with accepted academic practice. No use, distribution or reproduction is permitted which does not comply with these terms. 